\title{
Conflict Dynamics between Two Neighbours: Looking Beyond Federalism
}

\author{
Takele Bekele BAYU ${ }^{1 \odot}$
}

Ethiopia is a multicultural and multilingual country. The Oromo and Somali communities are found in the same linguistic community, that is, the Cushitic language. Historically, Somalis and Oromo have a long tradition of co-existence and strong socio-cultural interactions, as well as antagonistic relationships and intermittent conflicts. Traditionally, the major sources of conflict between the two communities were competition over scarce resources, territorial expansion, livestock raids and counter raids, kidnapping for marriage purposes and the revenge tradition. However, this time the conflict took a different nature, form and bigger scale causing devastation never seen in the history of communal conflict in the country. The study has utilised primary and secondary data collection and employed narration and content analysis to realise the objective of the paper. The findings of this study reveal that the causes of the Oromo-Somali conflict are complex and dynamic. This urges the need to carry out a deeper investigation beyond the federal arrangement. Thus, fundamental and triggering factors including the involvement of internal and external forces, the collapse of social norms and prevalence of moral anarchism, socio-economic issues, competing interests among public and military officials, poor leadership and governance system, competing interests over resources, aspects of local cultural institutions in regulating inter-ethnic relationships are identified in fuelling ethnic conflict in the studied area. Since the conflict in the region is much more complex than the dominant narrative of resource scarcity and ethnic politicisation, open democratic dialogue, genuine consultation and negotiation at a different level with various interest groups, stakeholders and community representatives, militant groups operating in the area is of paramount importance to ease the increasing ethnic tension and political crisis in order to build sustainable peace in the region.

Keywords: Ethiopia, Oromo, Somali, ethnic conflict, ethnic relation and federalism 


\section{Introduction}

\section{Background of the Oromo-Somali conflict dynamics - Coexistence and ethnic tension}

Ethiopia is a country situated in the Horn of Africa; it is the second-most populous nation in Africa after Nigeria, with a population of 108 million in 2018. ${ }^{2}$ The country is bordered by Eritrea to the north, Djibouti to the northeast, Somalia to the southeast, Kenya to the south, Sudan and South Sudan to the west. Despite the fact that the country is rich in minerals, natural resources and vast fertile land, it happens to be one of the poorest countries in the world in Gross Domestic Product (GDP) per capita term, $\$ 767.56 .{ }^{3}$ Ethiopia is very diverse with more than 80 ethnic groups, and to name a few among them are Somalis and Oromo.

Following the 1994 constitution, the country is divided into nine regions and two city administrations. The Oromia and Somali regional states are the two largest regions in the Ethiopian federation. The Oromo and Somali communities are members of the Eastern Cushitic linguistic group of the Horn of Africa. Historically, Somalis and Oromo have a long tradition of co-existence and strong socio-cultural interactions. They relate to each other in terms of language, religion and culture. Though the Somali communities live in the state of Somalia, they also live in different countries in the Horn of Africa including Ethiopia, Kenya and Djibouti. They all share the same identity (the Somali identity) and religion. However, they do have various clan systems which are indeed considered a point of difference among the Somali community. The Ethiopian Somalis have genealogical and kinship relations with the Somalis living in other parts of the Horn of Africa like in Somalia, Djibouti and Kenya. For instance, the dominant Somali clan living in the state of Djibouti categorised under the same clan along their Ethiopian counterparts called Issa Somali and ruled under the same clan leadership called Ugaas (title of Somali traditional leader). There is sometimes cooperation and other time disputes among and between the various Somali clans in the Horn of Africa. The Somalis practice Islam almost exclusively and are largely engaged in nomadic pastoralism. In contrast, the Oromo practice Islam, Christianity and traditional religions. However, large numbers of the Oromo population who live along the shared border with the Ethiopian Somali follow the Islamic faith and are predominantly engaged in pastoralism. The Somali and the Oromo ethnic communities represent the dominant pastoral groups in Ethiopia.

There are similarities and differences between the two groups when it comes to their relationship with the Ethiopian Government. The Somali community is cornered at the geographic and political periphery in the history of Ethiopian politics. However, the Oromo had played a key role in Ethiopian politics particularly since the beginning of the

2 Worldometer, Department of Economic and Social Affairs, Population Division, World Population Prospects, 2017.

3 The World Bank Group, GDP per capita (current US\$), 2018. 
$20^{\text {th }}$ century. ${ }^{4}$ Under the new ethnic based federal ${ }^{5}$ restructuring, the Oromo and Somali regional states share the longest internal boundary in the Ethiopian federation (more than $1,000 \mathrm{~km})$.

As an adjacent community, the Somali and Oromo share common values and traditions. ${ }^{6}$ These include close linguistic affinity, shared Islamic faith, economic interdependence and shared cultural practices including flow of individuals across ethnic boundaries through intermarriage. In effect, they developed strong interethnic solidarity and alliances. For instance, historically the two communities had stood together against the Christian highland domination. Particularly, people around the shared border areas identify themselves with dual identity (Somali-Oromo identity). Here it is important to quote Kelkelachew Ali:

There existed generations-old cultural and linguistic transactions and widespread affiance relationships between the two ethnic groups. This phenomenon has resulted in the cross-cultural fertilization and acculturation whereby similarity of many cultural traits, including bilingualism of the overwhelming majority of the people from both groups took place. ${ }^{7}$

Despite the aforementioned communalities and close relationship, the Somali and Oromo had experienced and still experience antagonistic relationships and intermittent conflicts. ${ }^{8}$ Historically, there were intra- and inter-ethnic group conflicts in the region due to factors like climate variability, recurrent droughts and endemic poverty, fierce competition over scarce land and water sources, territorial expansion, livestock raids and counter raids. ${ }^{9}$ Although conflict in the region is as old as the community, the nature, behaviours and trends of conflict have become complex, dynamic and the result of the interplay of factors resulting in huge repercussion. Particularly the newly introduced political and structural changes in the country since 1991 have politicised the existing conflicts over natural resources. ${ }^{10}$

In the pre-federal state, the two ethnic groups along the shared border dealt with non-ethnic based administrative province and in effect, disagreements were settled through a common approach to shared resources, culture and governance systems. For

4 Christopher Clapham, Transformation and Continuity in Revolutionary Ethiopia (Cambridge: Cambridge University Press, 1988), 217.

5 Ethnic federalism includes ethnically defined national citizenship, self-determination on an ethno-linguistic basis as enshrined in the constitution, ethnically defined political representation and decision-making at all administrative levels and related policies.

${ }^{6} \quad$ Mohammud Abdulahi, The changing nature of pastoral conflicts in south-eastern Ethiopia: The case of the Boran and Digodi pastoralists (Africa Peace Forum, Pastoralist Concern Association Ethiopia, Interafrica Group, Saferworld, 2005), 7-17; Kelkelachew Ali, Conflict and Conflict Resolution in Somali Regional State (Final consultancy report for GTZ, Capacity Building in Governance Conflict Prevention 1 Transformation CPT, under the Ministry of Federal Affairs (MFA), Addis Ababa, 2005), 39.

$7 \quad$ Ali, Conflict and Conflict Resolution, 39.

8 Abdulahi, The changing nature of pastoral conflicts, 7-17.

9 Mesfin Getachew, 'Ethnicity and Ethnic-Conflict in Post-Federal Ethiopia: A case of Ma'eso District Conflict between Oromos and Somalis', EPU Research Papers no 03/06 (2006); Personal Interviews, 'Displaced ethnic Oromo and Somali', Dire Dawa, 19 July - 18 August 2018.

10 Getachew, 'Ethnicity and Ethnic-Conflict. 
instance, the Ma'eso and Babile districts, which are now contested districts between the two regions, were administered under the same administration called Hararge provincial administration. Similarly, the currently contested town Moyale and its surrounding were administered under the Sidamo provincial administration. Consequently, reports of violent conflicts between Somali and Oromo people along the shared border in the pre-federal state were rare and easily arrested through common formal and informal institutions.

However, the 1991 decentralisation system restructured the aforementioned districts along ethnic lines. Consequently, residents living in those districts were put under Somali and Oromo regional administrations with no clearly demarcated border between them. ${ }^{11}$ The new system introduced in 1991 is wrapped up with the creation and implementation of boundaries to distinguish ethnic based limits. For instance, the 1991 decentralisation system restructured the aforementioned districts along ethnic lines and in effect, residents living along those districts were put either in the Somali region or the Oromo regional administration with no clearly demarcated border between them. ${ }^{12}$ This situation has transformed the nature of conflicts in the area from one caused dominantly by resource competition into a kind of conflict in which boundary issues play an increasingly significant role. ${ }^{13}$ Further, the conflict in the region has been complicated by the involvement of multiple actors and forces from federal, regional, local governments to external state and non-state actors. ${ }^{14}$

Since 1992, inter-regional boundaries that divide the Somali region from its neighbour Oromia have been ill-defined and in effect, there have been violent conflicts along the commonly shared borders. The two regional administrations through the federal government mediation had sought for political and legal solution to their border problem and staged various consultation platforms. But all efforts had ended fruitless and failed to address contested territories between the two regions. For instance, in 2004-2005 the federal government has intervened as per to the constitutional provisions and carried out a referendum on contested areas. The result of the referendum has conferred 80 per cent of the disputed territories to the Oromia regional state. ${ }^{15}$ This has disappointed their Somali counterparts. Consequently, violent conflicts have erupted in the various districts and towns along the shared borders of the two regions, that is, Mullu, Asabot, Bardode, Moyale, Iften and Bable among others, with devastating outcomes - large-scale destruction of livelihoods, loss of lives and massive displacement of people. A case in this discussion includes that the Issa Somali were displaced from Bordede of Oromia region and were settled in Mullu district (the Hawiya clan) and the Ittu Oromo were also displaced from

11 Ibid; Ahmed Shide, Conflicts along Oromia-Somali States Boundaries: The case study of Babile district (First national conference on federalism, conflict, and peace building, organized by the Ethio-German co-operation (GTZ) of the Federal Governance Development Project in collaboration with the Ministry of Federal Affairs, Addis Ababa, 2004).

12 Shide, Conflicts along Oromia-Somali States Boundaries.

13 Personal Interviews, 'Displaced ethnic Oromo and Somali'.

14 Abdulahi, The changing nature of pastoral conflicts, 7-17.

15 Faisal Roble, 'Roots to the Somali Massacre: Challenging False Narrative', Wardheer News, 27 September 2017; Salem Solomon, 'What’s Driving Clashes Between Ethiopia’s Somali, Oromia Regions?', Voice of America, 29 September 2017. 
Bike of Somali region and were settled in Me'aso district. ${ }^{16}$ The federal government has restrained from enforcing the result of the referendum due to fear of further escalation of conflicts along the shared border areas. Since then, therefore, full demarcation has never occurred between the two regions, which thought to have contributed to the ongoing border crisis in the region.

However, the federal government has orchestrated consecutive meetings between the officials of the two regions at federal, regional and district levels with the view to minimise the hatred sentiments and animosity between the local elites and communities of the two regions. Various joint conferences were held between communities and administrations along the disputed border. Furthermore, in 2005 the two regions have established 'joint peace committees' (JPCs) at regional, zonal and district levels. They also agreed to formulate 'joint development and security co-operation programs and law enforcement' to prosecute the unlawful practices and human right violations committed in the disputed border areas. Though all these efforts have contributed to de-escalate conflicts, they did not bring significant and sustainable results to the problem. ${ }^{17}$

Consequently, since early September 2017 an ethnic based crisis that has never been seen in the history of the country erupted along the shared border of the two regions. The conflict has displaced nearly 857,000 people from both communities. Nearly all districts along the shared border were affected by the conflict. The conflict drastically changed its shape, course and nature over time from local level territorial conflict to intra-federal boundary dispute with the involvement of multiple actors and forces and from a simple confrontation by using traditional weapons to war-like scenarios with modern and more sophisticated weaponry resulting in mass death and displacement. This has increased the complexity and intractability of the conflict between the Oromo and Somali communities. Ethnic conflicts in Ethiopia in general and ethnic based conflict between the Oromo and Somali communities in particular are domestic affairs and must be treated under noninternational armed conflict. Accordingly, the 1949 Geneva Conventions and Additional Protocol II of 1977 that calls for the need to ensure a better protection for the victims of those under armed conflicts would have much relevance in dealing with domestic conflicts like the Somali-Oromo case. ${ }^{18}$ However, the Oromo-Somali conflict would have regional implications given the Somali kinship adherence in the Horn of Africa (hereafter: HoA). In effect, regional organisations like the Intergovernmental Authority on Drought and Development (IGADD) can play a positive role in the development of security regionalism in close collaboration with member states since its top priorities are conflict prevention and resolution concerns in the HoA. ${ }^{19}$ Therefore, this particular paper has attempted to

16 Zigale Tamir Tenaw, 'Indigenous institutions as an alternative conflict resolution mechanism in eastern Ethiopia: The case of the Ittu Oromo and Issa Somali clans', African Journal on Conflict Resolution 16, no 2 (2016), 85-95.

17 Muhyadin Odowa Liban, Local conflicts between Somali and Oromo people in the context of political decentralization in Ethiopia. Comparative case study on Ma'eso and Babile Districts (Unpublished MA thesis, Institute of Social Studies, Kortenaerkade 122518 AX, The Hague, 2006), 21-31.

18 United Nations, Protocol Additional to the Geneva Conventions of 12 August 1949, and relating to the Protection of Victims of Non-International Armed Conflicts (Protocol II), of 8 June 1977.

19 Katja L Jacobsen and Johannes R Nordby, Danish Interests in Regional Security Institutions in East Africa (Copenhagen: Danish Institute for International Studies, 2013). 
examine ethnic conflict dynamics along the shared border of the Somali and Oromia regional states in the Ethiopian federation and recommend the way forward.

\section{Statement of the problem}

Various research studies conducted in the study area tend to generalise that ethnic conflict in the study area is solely the result of ethnic federalism and its associated politicisation. Although the adoption of ethnic federalism as a diagnosis and response to Ethiopia's century-long divisions between nationalities and history of exploitation has created further challenges at various levels in the country, attributing the federal system for the entire crisis that Ethiopia is facing is wrong and fatal. The truth in the above explanation is that the new political and administrative arrangements has politicised the existing resource based conflict and thereby transformed local resource based incidences into an interregional state boundary dispute which in turn created hostility and mistrust between the Somali and Oromo ethnic communities. However, the explanation and analysis of conflict in Ethiopia including the Oromo-Somali conflict goes beyond the federal arrangement. Ethnic conflict in the study area is the result of combinations of forces including sociocultural, historical, economic, political and environmental factors. This urges the need to carry out a comprehensive investigation and analysis on the dynamic nature of ethnic conflict in the study area. Therefore, this particular study is tasked with investigating conflict dynamics between the two neighbours (Somali and Oromo communities) while looking the issue beyond the federal centred analysis.

\section{Research objective}

The purpose of this study is to investigate and analyse forces responsible for the OromoSomali conflict beyond the federal arrangement.

\section{Research questions}

What are the major sources of ethnic conflict in the study area? How do you explain those factors? Who are the actors in the conflict in the study area?

\section{Methodology}

The study employed qualitative research approach. 


\section{Types, sources and instruments of data collection}

To realise the purpose of this study, primary and secondary data types were used.

Primary qualitative data was gathered using tools like personal interview, thereby enabling the capture and discovery of experience, perceptions, feelings, or emotions regarding factors of ethnic conflict from internally displaced individuals/groups (Somali and Oromo ethnic members displaced due to the conflict and settled as refugees at the Dire Dawa city administration). The study has also intensively utilised secondary data sources that include books, legal and policy documents, internet articles, research articles by other researchers (journals), databases and other sources.

\section{Methods of data analysis}

The study employed qualitative data analysis, particularly content and narrative based analysis. Further, desk based analysis was also utilised to analyse relevant documents related to the issue.

\section{Result and discussion}

Various studies on conflict analysis in the region rushed to blame federalism and associated politicisation of ethnicity as well as traditional sources like competition over scarce resources for all of the problems and crisis related to ethnic conflict along the shared border of the two regions. The aforementioned factors play a significant role in instigating ethnic conflict in the study area but limiting conflict analysis to merely those factors would be shallow and fundamentally flawed. In the real world, there is no single conceptualisation of conflict that can capture the variety of variables, including cultural, historical, political and economic motivations and multiple interests of the various parties involved in the conflict. Explaining the roots of contemporary conflicts in the study area requires deeper investigation and analysis. Therefore, forces that drive communities along the shared border of the two regions into ethnic conflict are complex, dynamic and multidimensional that cannot be examined in a simplistic term. Broader forces, that is, historical, institutional/structural/political, economic, socio-cultural and environmental factors must be taken into account in explaining the ethnic conflict in the study area. Therefore, the recurrent and dynamic nature of the Somali-Oromo conflict must be seen as a nexus between interplay of factors including changing political and administrative dynamics at macro and micro level, emerging identity construction and/or reconstruction, the collapse of social norms, and prevalence of moral anarchism, socioeconomic dynamics, competing interests among public and military officials, leadership and governance system, internal and external forces, competing interests over resources, aspects of local cultural institutions in regulating inter-ethnic relationship in fuelling the conflict. A broader discussion and analysis on the results of the personal interview and document analysis are presented here below. 


\section{The involvement of multi-layered actors with competing interests}

In the past, conflicts in the region were limited in scope, nature, impact and participants. As a result, the conflict attracts only local actors and its impact is limited to local districts as revealed in the personal interview. ${ }^{20}$ However, the conflict that erupted since September 2017 is violent and destructive causing mass death, displacement, violations of human rights and destructions of property that has never been seen in the country's long history of conflict. ${ }^{21}$ This is largely attributed to the presence and active involvement of various internal and external actors in the conflict. There are claims, reports and evidence that show the involvement of the following bodies in the local conflict: top regional and federal government officials, top military personnel, paramilitary and militia forces, rebelled armed groups, as well as forces from the state of Somalia.

In the past, it was common to see federal and local officials trying to work together to find common grounds so as to arrest the conflict and minimise its impact. However, in the new wave of conflict, severe political confrontation, suspicions and accusations have occurred among regional and federal government public figures as well as high rank military personnel that has further complicated the conflict. On top of this, the active involvement of paramilitary and militia forces and armed rebel groups siding their ethnic groups has fuelled the conflict on the ground which is unprecedented in contemporary Ethiopian history. ${ }^{22}$ Personal interviews conducted with both groups reflect that the Ogaden National Liberation Front (ONLF) siding the Somali community and the Oromo Liberation Front (OLF) siding the Oromo community have been actively involved in the conflict by providing small-scale weapons and ammunition to their respective ethnic group. ${ }^{23}$ There is accusation and counter accusation between the top leadership of the two regional governments, the one blaming the other for secretly working with and covering the hidden hands of the two formerly labelled terrorist organisations, that is, ONLF and OLF in the local conflict. ${ }^{24}$ Public figure finger pointing would not only affect political trust at the top leadership level but also would impact interethnic relationship since public opinion is largely shaped by the political elites. The quote here below is evidently underlining this:

In both regions - Oromia and Somali - regional officials at all levels neither behave as part of the federal system nor take responsibility to protect the welfare of all Ethiopians particularly the lives and properties of peoples of the neighboring regions. They rather consider themselves as "good" ethnic/clan leaders and "defenders" of their ethnic territories". ${ }^{25}$

\footnotetext{
Personal Interview, 'Displaced ethnic Oromo and Somali’.

Ibid.

BBC, 'What is behind clashes in Ethiopia's Oromia and Somali regions?', 18 September 2017; Dawit Endeshaw, 'Federal forces intervene in Somali-Oromia conflict', The Reporter, 16 September 2017; Solomon, 'What's Driving Clashes'.

23 Personal Interview, 'Displaced ethnic Oromo and Somali'.

24 BBC, 'What is behind clashes'?

25 Asnake Kefale, Federalism and Ethnic Conflict in Ethiopia. A Comparative Regional Study (Routledge, 2013).
} 
Parallel to this, the personal interviews conducted with displaced respondents from the Oromia region have revealed that the 'Liyu police', a special police force based in the Somali region has played an active role in igniting the conflict and aggravating the situation. The 'Liyu police' as a paramilitary force was officially organised under the Somali regional government and has been receiving military training and equipment from the Ethiopian People's Revolutionary Democratic Front (EPRDF) with the presumption that it is battling the then terrorist organisation, the Ogaden National Liberation Front (ONLF), a separatist faction that demands self-rule for Somalis, but now are pardonned by the government and cancelled from the national terrorist list. Though it has contributed in the fight against terrorist groups like Al-Shabaab in the region, the 'Liyu police' was accused of working for and protecting the interest of the corrupt leadership at the regional level led by the former president Abdi Mohammed Omar - and the TPLF corrupt leadership at the federal level who were actively engaged in illicit trade and contraband business along the Ethiopian Somali and Djibouti border. Furthermore, the Oromo activists as well as the Oromia regional state's higher officials were accusing the 'Liyu police' for its alleged involvement in mass killings and displacements of ethnic Oromo along the shared border of the two regions. According to Mr Addisu Arega, the then Oromia regional government's spokesperson, 'in February and March of 2017 hundreds were reported to have been killed in the southern Oromia district of Negele Borena after an incursion by a paramilitary force called the Liyu Police'. ${ }^{26}$ Mr Addisu has further accused the Somali regional administration and its security apparatus of secretly working with and inviting the national army of the Federal Republic of Somalia into the conflict. ${ }^{27}$

The Somali regional government on its part was accused by the Oromia regional state's high ranking official of providing home base for the OLF from where they carried out an attack against ethnic Somalis. The Somali regional government held the Oromia regional state and the OLF responsible for the killings of ethnic Somalis in the Oromia town of Awaday on 11 September 2017 where more than 50 Somalis were killed although the figures are disputed by the Oromia regional government. ${ }^{28}$ Moreover, the personal interview conducted with displaced ethnic Somalis demonstrates that 'the Oromia Police was irresponsible and failed to protect the Somalis, including mass killings, lootings and displacement of ethnic Somalis'. ${ }^{29}$ Apart from this, the Oromo and Somali activists and neutral observers are accusing the TPLF dominated Ethiopian People's Revolutionary Democratic Front (EPRDF) in aggravating the conflict in the study area. The party and its officials, specifically the TPL, were deliberately siding with the Somalis, which was not only geopolitically important but also provided vital sources of illegal income for the top leadership. ${ }^{30}$

Moreover, the geopolitical and economic interests of the state over the borderland have made the conflict between the two groups complex. Because of the economic and political interests of government authorities at the centre, the state playing an impartial

26 BBC, 'What is behind clashes'?; Solomon, 'What's Driving Clashes'.

27 Endeshaw, 'Federal forces'.

28 Ibid.

29 Personal Interview, 'Displaced ethnic Somali', Dire Dawa, 15-18 August 2018.

$30 \quad$ BBC, 'What is behind clashes'?; Endeshaw, 'Federal forces'; Solomon, 'What's Driving Clashes'. 
role in the conflict made conflict resolution and peace building difficult in the region. ${ }^{31}$ Consistent with this view, various scholars have recognised the active role of the state in igniting conflict in the different parts of the world. ${ }^{32}$ The federal government plays a more strategic manipulative role when it comes to its economic and security interest. ${ }^{33}$ The other important point that has to be made here is that the federal government is not proactive, it rather reacts once the conflict has erupted. On top of this, instead of securing the peace and security of its people, the federal government seems more concerned with its economic and political interests. ${ }^{34}$ Therefore, because of the aforementioned factors, the contemporary Somali-Oromo conflict is complex and dynamic involving various internal and external forces.

\section{Lack of good governance at different levels}

Among others, the new state restructuring aimed at granting nations, nationalities and people of Ethiopia the right to self-administration, protect their distinctive socio-cultural and linguistic identity and bring government closer to the people through decentralisation to ease the provision of goods and services. Consistent with this, various legal and other programs of reforms have been designed to enhance good governance and democracy at the grassroots level. However, one party domination in the political system and the notion of 'democratic centralism' in the last three decades not only paralysed the political landscape but also made citizens develop a kind of attitude that their vote has no power to bring any difference since the political culture has made elected government to be accountable for the party channels, instead of ensuring accountability for their constituencies. The existence of political and economic marginalisation, rampant youth unemployment and resource competition continues to spark conflicts negatively impacting peace and security, and economic development across the country. Due to lack of democratic culture, the erosion of the rule of law, party monopolisation of the economy, as well as the politicisation of the civil service, the incidence of grand and petty corruption continued to be major sources of bad governance, which constitute a major explanation of ethnic conflict in the country. It is common to find in different government reports that bad governance and mass unemployment are the two main forces challenging the country's positive economic growth and accelerating poverty reduction. The situation is more complex and challenging as one moves to the lower levels of administration.

The Somali-Oromo conflict needs to be understood and analysed within the framework of good governance. Like laws and provisions at the federal level, the Somali and Oromia regional states have their constitutions and other relevant instruments designed to ensure components of good governance like accountability, transparency, participation, effectiveness and equity, and the rule of law in their respective territories.

31 Nancy Peluso and Michael Watts eds, The Violent Environments (Cornell: Cornell University Press, 2001).

32 Raymond Bryant and Sinéad Bailey, Third World Political Ecology (London - New York: Routledge, 1997); Norman Long, Development Sociology. Actor Perspectives (London: Routledge, 2001).

33 Kefale, Federalism and Ethnic Conflict.

34 Personal Interview, 'Displaced ethnic Oromo and Somali'. 
However, both regions have failed to address the needs of their citizens, and in effect, lack of good governance has become the dominant source of ethnic conflict in both regions. The following manifestation of bad governance played a major role in igniting conflict between the two communities.

\section{Weak law enforcement}

Weak control and regulation of the federal government over the region's use and mobilisation of funds in the peripheral regions including the Somali state has created a breeding ground for corruption and misuse of funds for unintended purposes in the name of peace and security. Further, poor control of the movements of light and heavy arms and weapons along Ethiopia's border with neighbouring states such as Kenya and Somalia as well as weak internal control along the shared border between the two regions has created easy access to military equipment. ${ }^{35}$ In this regard, conflicts in the past in the area were indeed less devastating as they mainly involved the use of traditional weapons such as bows, arrows and spears. However, the widespread availability of small arms and light weapons has significantly increased devastation in the region. That is why the recent conflict virtually looks like warfare when we look at the number of causalities from both sides.

Weak law enforcement has been observed at both level of government. The federal government has failed to protect the constitutional rights of citizens; the right of people's movement across the nation. Eviction and displacement of the so-called 'non-indigenous citizens' by local and regional government officials and even sometimes in conspiracy with top federal officials is common in Ethiopia. A case to mention is the Oromo eviction from the Ethiopian Somali regional state and vice versa before the eruption of the all-out conflict between the two ethnic groups. And surprisingly no one has been held responsible. The federal government has also failed to enforce the results of the 2004 political referendum on border demarcation. This failure, whatever the reason behind it might be, has resulted in the eruption of violent conflict that has never been seen between the two ethnic groups. ${ }^{36}$ Hence, weak institutional enforcement as well as lack of political commitment at the federal government can be mentioned worthwhile in igniting the recent conflict between the two groups.

At the regional government level, officials from both sides failed to collaborate with the federal government in implementing the referendum result. Regional leadership has also failed to enforce the various peace and security agreements signed between the two regions. For instance, the two regions have signed a peace pact in April 2017 with the view to calm down the situation and bringing peace along the shared border. During the agreement, the two leaders (Lema Megersa of Oromia and Abdi Mohammed of Somalia)

35 Kassa Getachew, 'An overview of root causes of problems that currently affect Boi'ana pastoralists of southern Ethiopia', in Resource Alienation, Militarisation and Development: Case Studies from East African Drylands, ed. by Mustafa Babiker (Khartoum - Addis Ababa: Proceedings of the regional workshops on east African drylands, 2002), 67-76.

36 Personal Interview, 'Displaced ethnic Oromo and Somali'. 
displayed a historic gesture of unity where the two regions appeared to have resolved their issues and were said to have reached an agreement to complete the border demarcation process pursuant of the 2004-2005 referendum. However, they failed to respect the terms of the pact. Instead of finding common solution to the problem, regional leaderships engaged in political confrontation and trading blames and accusation and counter accusation one against the other. This has worsened the situation on the ground. Therefore, if the regional leadership had showed good will, political commitment and leadership skills then it would have been easy to manage the conflict and minimise its impacts.

\section{Lack of accountability and transparency}

Local governments in Ethiopia are not functioning well to meet good governance demands though they are designed to promote efficient and equitable governance through transparency, accountability, grassroots participation and the rule of law.

The personal interview conducted with both groups reveals that ethnic based recruitment of servants and partiality in the distributions of goods and services are the main drivers of conflict between the Oromo and Somali communities along with the shared areas of the two regions. ${ }^{37}$ For instance, the following disappointments have been expressed in the discussion:

Public officials in both administrations along the shared border areas employ discriminatory rules and regulations to benefit their ethnic base and recruit human personnel to different sectors based on ethnic identity though people along the shared border speak both Oromo and Somali language as well as have mixed identity and identify themselves with a dual identity. There are differences

in treatment when it comes to access to public goods and services, resources and employment since public institutions are ethnicized and made to serve their kinship. ${ }^{38}$

\section{Social and mainstream media pressure}

Media is a double-edged sword. On the one hand, in a country like Ethiopia responsible media (both traditional and social media) can play a huge role in democratising society and can serve as a system of checks and balances in regulating government behaviour and actions. Social and mainstream media can inculcate democratic values and norms in the minds of citizens thereby play an irreplaceable role in the creation of responsible citizenry. To execute these golden societal duties, media must operate within the legal framework and according to professional principles and values. When they do this, media can be a verification force and a place platform for rational discussion paving the way in building a democratic society and ensuring an accountable and responsible government. On the

Personal Interview, 'Displaced ethnic Oromo and Somali'.

Ibid. 
other hand, given the consciousness of the mass and the lack of policy and legal framework, unchecked media particularly social media would be catastrophic pushing the country toward ethnic violence, political instability and even greater calamity.

In Ethiopia, both public and privately owned media are not committed to society's coexistence. Instead of advancing values like trust and tolerance to prevail between groups, they rather engage in political propaganda as the government mouthpiece and spread bad old narrations and memories that happened once in history but actually have no value for coexistence and are rather used to separate groups. Social media is also used irresponsibly to portray hate speech, bad memories to agitate one group over the other. Getachew Dinku, Head of the School of Journalism and Communication at Addis Ababa University (AU), has indicated that offensive messages, fake news, hate speeches, irrational arguments, messages that are intended to instigate chaos and conflicts and identity theft or violation of privacy are some of the problems that prevail in social media in Ethiopia. As a result, 'we need to create our ways of crafting the ethics of the public to avoid the side effects of these media' ${ }^{39}$ Here it is worth to mention and quote the comments on social media of Lidetu Ayele, founder of the opposition Ethiopia Democratic Party: 'The problem is a lot of things people view as gossip if heard by mouth, when they read about it on social media they take as fact. ${ }^{30}$ The personal interview with both groups demonstrates that mainstream medias owned by both the regional government and some private medias and people on social medias have conflict of interest in the situation and all acted irresponsibly by portraying bad images, spreading fake news, mistrust and intolerance to prevail adding fuel to the conflict between the two ethnic groups, Oromo and Somali. ${ }^{41}$

The weaponisation of social media by various entities paved the way in spreading false and manipulative narratives with phenomenal cases. For instance, in the 2016 Irreecha festival celebrated by the Oromo community. During the festival, a clash occurred between the police and protestors, which left more than 100 people crushed or stamped to death. Surprisingly, people on social media buzzed with claims that a police helicopter had fired into the panicking crowd. However, the truth is that the police helicopters dropped leaflets, not live fire or bombs, wishing participants a happy festival. The misinformation and fake news has ignited emotions among the youth and led to the destruction of foreignowned factories, the privately owned flower industry, government buildings and tourist lodges across the Oromia region, which led the government to declare a six-month state of emergency.

The other point worthy of mentioning here is that the public takes for granted the news and reports of diaspora owned satellite television broadcasted from the United States, such as the Oromia Media Network and the Ethiopian Satellite Television. Indeed, they do produce decent original reporting, but they are not neutral and are often one-sidedly portraying only the bad image of the ruling party. The effect here is that their viewers take the stories for granted and propagate it on social media.

39 Henok Tibebu, 'Crafting Social Media for Better Tomorrow', 23 November 2017.

40 James Jeffrey, 'Ethnic Violence in Ethiopia Stoked by Social Media from U.S.', IPS News Agency, 11 February 2018.

41 Personal Interview, 'Displaced ethnic Oromo and Somali'. 
Therefore, media (traditional, modern, mainstream and social media) can play a major role in peacebuilding by advancing values that are of paramount importance for coexistence or conflict by spreading hatred, mistrust and intolerance between communities. Indeed, responsible media work for the creation of a free and responsible society. However, irresponsible media work for the separation of communities by spreading hatred and fake news. This calls for coordinated effort amongst all stakeholders to come up with a sound public policy paving the way for social media to contribute to the nation's socio-economic and political progress. There is also a need to balance and address the tension between repressive media and media freedom in the country by designing appropriate proclamation through active participation from all stakeholders. Though the western liberal style of free media is not possible, yet a media code of conduct and core obligation is needed in Ethiopia to make media individuals and entities operate within the constitutional framework and other laws of the land to guarantee the democratisation of society and its system.

\section{Mass youth unemployment}

As indicated above, mass unemployment and bad governance are the two main forces challenging the country's positive economic growth and accelerating poverty reduction. Indeed, these are the forces responsible for the violent - sometimes peaceful - protests that rocked the country since 2015. The economy in general is not as effective as it is thought when it comes to job creation. This is primarily due to the prevalence of corruption and rent seeking political economy. In effect, mass youth unemployment is common in every part of the country. This has created a fertile ground for conflict entrepreneurs to mobilise the youth for their private benefits. In this regard, EPRDF old guards, a group who lost power at the federal level in the recent political shake up and reform, and corrupted regional and local officials, who feel discomfort with the new political dynamics, were accused of organising the unemployed youth from their respective ethnic groups and by funding them of destabilising the country. In effect, ethnic based conflict and political instability is common in every parts of the country. Due to years of EPRDF governance policy, which primarily focused on ethnic division and differences, made the young generation intolerant to one another. In both regions, irresponsible and corrupt officials have organised the unemployed youth and it is through them that these officials satisfy their economic and political needs. Organised youth taking the agenda of corrupt officials and driven by emotional claims and counter claims have played a major role in initiating and fuelling the Somali-Oromo conflict. ${ }^{42}$ Although respective religious and clan leaders have attempted to calm down the youth, all are too late to contain the emotional claims.

${ }^{42}$ Personal Interview, 'Displaced ethnic Oromo and Somali'. 


\section{The new political dynamics at the federal level}

When the political economy of a given country is dominantly controlled by certain ethnic groups, then others would actually suffer from injustice and unequal access to state power. This situation unavoidably creates conflicts within the ruling power and in the wider public. This is what happened in the Ethiopian context. The domination of one ethnic group within the EPRDF coalition government has led to the development of mistrust, disagreement and conflict between member parties. Further, the domination of certain ethnic groups in the political economy coupled with the prevalence of corruption has led to the dissatisfaction of the mass, particularly the younger generation. In effect, for the last three years the country has been rocked by mass violent protests, which first occurred in the two largest ethnic group regions, Amhara and Oromo but later on spread across the nation threatening the very existence of the state. Indeed, after the death of then Prime Minister Meles Zenawi, the central government is shaky and unstable due to the lack of a strong leadership that can absolutely control the party, as the government and the state witnessed during the Meles Era. Then, owing to the structural weakness of the federal government, various protests and conflicts erupted in the country. Particularly, the unstable federal government is unable to command effective control over the peripheries including the Somali and Oromia shared border areas. Indeed, after the death of Meles Zenawi, insecurity and incidence of conflict has increased in their region as if there is no government or change in government in the country. It is this time that the violent conflict has erupted between the Somali and Oromo ethnic communities along the shared border. ${ }^{43}$ It is thought that since the epicentre of mass protest is the Oromia region, conflict entrepreneurs at the federal and Ethiopian Somali region level have instigated conflict along the already tense and volatile Somali-Oromia shared border with the view to divert public attention and the protesters agenda as well as to keep the Oromia region weak and unstable.

As the mass protests and political instability across the nation show no sign of stop, Prime Minister Hailemariam Dessalegn resigned from power claiming to be part of the solution to the country's political instability and deadlock. This is unprecedented causing a huge crack within the coalition. The mass protests and the split within the coalition have forced the EPRDF government to introduce major political and economic reforms, which is now under implementation in most parts of the country. However, those who lost power at the federal level, particularly the EPRDF old guards, that is, the founders of TPLF and ANDM and corrupted political elites at region and local level who feel insecure by the reform are instigating conflict between ethnic groups as it harms some groups and benefits others, while cramming bad image and meaning to the ongoing reform. Hence, these groups have been accused of destabilising the country including fuelling the Ethiopian Somali-Oromo conflict.

43 Ibid. 


\section{Weak indigenous social and cultural institutions}

As it is well known in pastoral areas, there are long established cultural based institutions responsible in establishing rules and regulation on the utilisation and management of common resource areas. It is also common to observe resources based conflict in pastoral areas. Nevertheless, through this institution, conflict easily gets controlled before it erupts into violence. In the post-1991 political system, Ethiopia was arranged in 9 regions along ethnic lines and two administrative cities. ${ }^{44}$ In effect, common resource areas, which were in the past mutually utilised, have been territorialised in the same pattern creating problems to customary resource bases. In this regard, traditional resource based conflict has been politicised since territorial control enhances political power and economic interest of rival groups. ${ }^{45}$ With this, one can see the shift of power from traditional institution to the decentralised formal political system. This is justified by the fact that traditional leaders are representatives of their respective ethnic groups and possess decision-making powers over all aspects of their society. In contrast, government officials and the ethnic based elite actually possessed the state power and claim to have the same decision-making power over the society. Consequently, the political elites with the view to own more political and economic control and decision-making power over the areas purposefully worked to make traditional institutions including mechanisms for resolving conflicts either loyal to the political system or undermine their authority within the society. Hence, local politics has weakened traditional institutions as a means of conflict resolution and management.

Here, I find important to present and quote the works of the African Centre for the Constructive Resolution of Disputes (ACCORD) on conflict resolution in the area as follows:

Since the last few decades, these traditional institutions have taken ethnic lines in creating dichotomies rather than playing the negotiator role, building on common values and practices. The political background for the divergence of traditional institutions from the role of negotiating for social harmony to that of igniting inter-group animosity and differences is closely connected to the post-1991 political order in the country. ${ }^{46}$

Cultural institutions are politicised by the system and have poor public acceptance, trust and communicative power and above all, they stay with politicians as if they forgot what our society had in common with others. In effect, the politicised traditional institutions as well as their leaders have lost their decision-making legitimacy and moral authority because they are not making decisions on behalf of their respective ethnic groups, they rather serve the mere interest of the political system. Further, religious leaders and traditional elders are not committed as used to be. They are pursuing their economic interest, looking after the payment made by the government, to put literally per diem, for their assumed role in

\footnotetext{
44 FDRE, 'Constitution of the Federal Democratic Republic of Ethiopia', Federal Negarit Gazeta, 1994.

45 Getachew, 'An overview of root causes', 67-76.

46 Tenaw, 'Indigenous institutions as an alternative conflict resolution mechanism'.
} 
conflict management and peace building process. ${ }^{47}$ Hence, it is in their interest to prolong the conflict and create a vicious circle of conflict between communities in so far as they are obtaining their per diem, as revealed in the discussion. Others, loyal institutions as well as religious leaders and traditional elders who promote the needs and interest of the society have been overlooked and actively undermined by the newly emerging ethnic elites or local government officials with their own agendas. In effect, they are weak in capacity to regulate society's problems. Therefore, the illegitimacy and impotence of traditional institutions as well as their corrupt leaders and the incompatibility of the federal structuring with customary institutions have contributed to the current large-scale violent conflict to erupt.

\section{The collapse of social norms and prevalence of moral anarchism}

In the last two decades, the gradual deterioration of the moral fabric and foundation of the society can be observed in Ethiopia. Knowingly or unknowingly, it is common to see people's violation of moral values. Individuals as well as groups of individuals have failed to differentiate what is good from what is bad which presented a challenge in the creation of good and responsible citizenry. It is common to see citizens perusing values that go against toleration and coexistence. Mass killing, displacement and looting is currently a day-to-day activity in many parts of the country. Instead of working hard, people prefer to take a short path including killing others as a way to the creation of wealth which has never been seen in the history of the Ethiopian society. Religions and cultural institutions have failed to execute their natural and societal duties in the creation of responsible and good citizens not helping them uphold and practice ethics, morality and values of coexistence like respect, tolerance, open and civic mindedness. Today one can observe citizen's alienation from social, moral and religious norms and principles and in effect, citizens are not tolerant with each other. Indeed, respected local traditional and religious leaders advised the youth to be peaceful, respect long held values of coexistence, and ordered the youth not to attack fellow citizens who lived with them for years. However, the youth did not pay any attention to the leaders' advice, rather they threaten to attack them first and later on move to other neighbouring ethnic groups. ${ }^{48}$ Hence, old age values of tolerance and coexistence are now collapsing causing the prevalence of moral anarchism in the society.

\section{Concluding remarks}

The Oromo and Somali communities, due to their centuries-old interactions, have developed great common traditions and shared socio-cultural values. In the same token, the two ethnic groups have experienced antagonistic relationships and intermittent

47 Personal Interview, 'Displaced ethnic Oromo and Somali'.

48 Personal Interview, 'Displaced ethnic Oromo and Somali'. 
conflicts throughout their history of existence, though the nature, behaviours and trends of conflict varied from time to time taking new forms and dynamics with huge repercussions. Traditionally, the main sources of conflict amongst clans in the region are identified as competition over scarce resources, territorial expansion, livestock raids and counter raids, kidnap for marriage purposes and the revenge tradition. However, after the newly introduced political and structural changes in the country (Ethnic Federalism), the existing conflicts over natural resources have been transformed into inter-regional boundary disputes and conflicts involving multiple driving factors and forces. This has increased the complexity and intractability of the conflict between the Oromo and the Somali communities. Particularly the ongoing violent conflict, which is believed to be started in September 2017 in the strategic town called 'Chamuk' close to the Moyale district has never been seen in the history of the country's ethnic based conflict in terms of its magnitude, affecting nearly all districts along the shared borders and causalities, displacing nearly 857,000 people from both ethnic communities. Initially, the conflict erupted between the Borana, a dominant Oromo clan and Gerri, Somali clan, but later on the Gujji, the other Oromo clan, came as an alliance to support the Borana and fought the Garri. Traditionally, the Oromo consider the Borana their elder clan that deserves respect. In this regard, whenever the Borana were attacked by anyone, usually the attack came from the Somali, all other clans of the Oromo considered the attack as if it was conducted on all the Oromo community and fought in support of the Borana against the Somali. This is the way the conflict has started and became violent as well as spilled over across the shared border affecting thousands of people from both sides. Hence, this time the conflict took a bigger scale involving revenge and counter revenge as well as different actors and interest groups from local, regional, federal government and armed groups to external powers. With various efforts, the federal government tried to minimise and end the conflict between the two groups from deploying both the federal police and the national military forces to the area to organising post conflict peace building conferences involving responsible federal, regional and local authorities, religious and community leaders and the youth at large. Though such efforts are able to halt large-scale conflict in the area temporarily, small-scale conflict in the shared border area is persistent and above all, sustainable solution to the problem is far from being achieved. Therefore, the current Somali-Oromo conflict must be seen beyond ethnic federalism urging the government and stakeholders to consider other fundamental factors including the involvement of internal and external forces, the collapse of social norms and prevalence of moral anarchism, socio-economic dynamics, competing interests among public and military officials, poor leadership and governance system, competing interests over resources, aspects of local cultural institutions in regulating inter-ethnic relationship in fuelling the conflict.

\section{Recommendations}

Given the complex and dynamic nature of the conflict, open democratic dialogue, genuine consultation and negotiation at different levels with various interest groups, stakeholders, community representatives, militant groups operating in the area is of paramount 
importance to ease the increasing ethnic tension and political crisis and to establish sustainable peace in the region.

Federalism alone cannot bring peace and stability if not implemented along with democracy and good governance. In this regard, both qualities lack in the Ethiopian federalism and in effect, the government must work hard in ensuring democracy and good governance and in democratising societal culture. Hence, this paper urges the need to establish legitimate, capable, accountable and democratic authorities and leadership particularly at the local level where the challenge of good governance is immense.

The current federal arrangement merely takes into account ethnic lines while overlooking the commonly shared value system and crosscutting variables. Since the problem is structural, the political structure and economy of the state has to be restructured in accordance with realities on the ground, long-term societal security and development needs in the manner that would reduce ethnic tension and troubles in the country. Communities like Somali and Oromo share more common values than issues that separate them and in effect, reorganising the administrative territory taking into account crosscutting values and variables is necessary, where people along the shared border often identify themselves with a dual identity.

In order to minimise the recurrent nature of the Oromo-Somali conflict, the federal government in close consultation with the two regions must implement the results of the 2004-2005 border dispute referendum. Regional leaders should cooperate with the federal government for the full implementation of the agreed issues instead of accusing one another. The federal government instead of deploying the federal military should work hard to create trust between the two parties to take care with full responsibility of the issues of peace and security.

The current percentage of the population under 15 is 46.3 per cent and the percentage of the population between 15 and 64 years old is 51 per cent, which means that the Ethiopian population is young with most of them almost unemployed, that is, the youth dependency ratio is at 75.8. In effect, there is a huge youth unemployment rate in the country, which indeed causes ethnic violence and political instability across the nation. If the growing youth population is managed well through a sound policy, then it would create a huge opportunity for the entire economic development, otherwise it would be a curse and would present an enormous challenge and threat to peace and security. Hence, this paper urges the government and relevant stakeholders to take coordinated actions in reducing the youth unemployment rate by increasing production and productivity as well as promoting the culture of hard work while designing and implementing various job schemes and programs.

The current political dynamics in the country has brought great hopes and confusion at home. Abiy Ahmed's government has taken groundbreaking reforms. However, his reform vision is challenged by old guards of the former ruling party (EPRDF), patronclient corrupt leadership and unprecedented ethnic rivalry and violence. To set the reform on the track, priority must be given to national dialogue with political parties, to the rule of law, democratising institutional and societal values, setting the economy on the right direction and minimising the huge youth unemployment, reaching out and convincing various interest groups and communities of the fact that the reform benefits all. 
The current ethnic rivalry and violence is largely the result of the EPRDF's theory of governance which encourages ethnic competition over cooperation. This coupled with the politicisation of religious and cultural institutions has bred mistrust and hostility among and between various groups which in turn led to the collapse of social norms, the rule of law and prevalence of moral anarchism in the society. Hence, the government along with various state and non-state actors as well as community based cultural and religious institutions should work hard in establishing social harmony and tolerance as well as common interests and shared needs through increased cooperation and improved communication between various groups and communities to realise peaceful coexistence and a prosperous society in the country.

The absence of a decree, though currently under way, to hold Medias and individuals accountable for their behaviour and actions has worsened the conflict situation in Ethiopia. There is a need to have a sound media policy and policies related to hate speech and false information. This would increase the accountabilities and responsibilities of media entities and individuals while minimising the negative impacts. Apart from the government's efforts in the creation of responsible Medias and professionalism, regional organisations like IGADD in collaboration with international institutions and donor agencies should play their part in empowering Ethiopian journalists and media professionals on the role of the media in political violence.

Communities in the region have endogenous systems of promoting social cohesion and healing. Hence, as an active constitutive of state power, the government should empower traditional institutions and respect their values and autonomy so that they might practice conflict resolution to complement the state's peace building practices. Since traditional mechanisms alone cannot be enough for the management of the new challenges and changes in the region, it must be complemented with a modern way of conflict resolution and peace building. Since the region is the most volatile in terms of conflict and in effect, home for more fragile states like Somalia, Sudan and South Sudan, Ethiopia's political instability will have a spillover effect causing further political instability in the region. Furthermore, since Ethiopia has a historical role in the region in stabilising and fighting terrorism particularly in the state of Somalia, genuine support from the West and their multi-lateral institutions in building a robust state is of paramount importance not only to avoid the appearance of another failed and fragile state in the region but also for the fight against international terrorism. In effect, the West in general, the USA in particularly should help build the institutional capacity and capabilities of the state thereby Ethiopia can realise its democratic transition.

\section{References}

Abdulahi, Mohammud, The changing nature of pastoral conflicts in south-eastern Ethiopia: The case of the Boran and Digodi pastoralists. Africa Peace Forum, Pastoralist Concern Association Ethiopia, Interafrica Group, Saferworld, 2005. 
Ali, Kelkelachew, Conflict and Conflict Resolution in Somali Regional State. Final consultancy report for GTZ, Capacity Building in Governance Conflict Prevention 1 Transformation CPT, under the Ministry of Federal Affairs (MFA), Addis Ababa, 2005.

Baxter, P T W, 'Ethiopia’s Unacknowledged Problem: The Oromo’. African Affairs 77, no 308 (1978), 283-296. Online: https://doi.org/10.1093/oxfordjournals.afraf.a096985

BBC, 'What is behind clashes in Ethiopia’s Oromia and Somali regions?', 18 September 2017. Online: www.bbc.com/news/world-africa-41278618

Bryant, Raymond and Sinéad Bailey, Third World Political Ecology. London - New York: Routledge, 1997.

Clapham, Christopher, Transformation and Continuity in Revolutionary Ethiopia. Cambridge: Cambridge University Press, 1988.

Endeshaw, Dawit, 'Federal forces intervene in Somali-Oromia conflict'. The Reporter, 16 September 2017. Online: www.thereporterethiopia.com/content/federal-forcesintervene-somali-oromia-conflict

FDRE, 'Constitution of the Federal Democratic Republic of Ethiopia'. Federal Negarit Gazeta, 1994.

Getachew, Kassa, 'An overview of root causes of problems that currently affect Boi'ana pastoralists of southern Ethiopia', in Resource Alienation, Militarisation and Development: Case Studies from East African Drylands, ed. by Mustafa Babiker. Khartoum - Addis Ababa: Proceedings of the regional workshops on east African drylands, 2002, 67-76.

Getachew, Mesfin, 'Ethnicity and Ethnic-Conflict in Post-Federal Ethiopia: A case of Ma'eso District Conflict between Oromos and Somalis'. EPU Research Papers no 03/06 (2006). Online: www.aspr.ac.atlepu/researchlrp_0306.pdfon 0211 0/2006

Jeffrey, James, 'Ethnic Violence in Ethiopia Stoked by Social Media from U.S. IPS NewS Agency, 11 February 2018. Online: www.ipsnews.net/2018/02/ethnic-violence-ethiopiastoked-social-media-u-s/

Jacobsen, Katja L and Johannes R Nordby, Danish Interests in Regional Security Institutions in East Africa. Copenhagen: Danish Institute for International Studies, 2013.

Kefale, Asnake, Federalism and Ethnic Conflict in Ethiopia. A Comparative Regional Study. Routledge, 2013. Online: https://doi.org/10.4324/9780203759530

Lewis, Herbert S, 'The Origins of the Galla and Somali'. The Journal of African History 7, no 1 (1966), 27-46. Online: https://doi.org/10.1017/S0021853700006058

Liban, Muhyadin Odowa, Local conflicts between Somali and Oromo people in the context of political decentralization in Ethiopia. Comparative case study on Ma'eso and Babile Districts. Unpublished MA thesis, Institute of Social Studies, Kortenaerkade 122518 AX, The Hague, 2006.

Long, Norman, Development Sociology. Actor Perspectives. London: Routledge, 2001.

OCHA and the National Disaster Risk Management Commission (NDRMC), 'Ethiopia: Conflict Displacement Situation Report', 23 January 2018.

Peluso, Nancy and Michael Watts (eds), The Violent Environments. Cornell: Cornell University Press, 2001.

Personal Interview, 'Displaced ethnic Oromo and Somali'. Dire Dawa, 19 July - 18 August 2018.

Personal Interview, 'Displaced ethnic Oromo’. Dire Dawa, 19-24 July 2018. 
Takele Bekele BAYU: Conflict Dynamics between Two Neighbours: Looking Beyond...

Personal Interview, 'Displaced ethnic Somali’. Dire Dawa, 15-18 August 2018.

Roble, Faisal, 'Roots to the Somali Massacre: Challenging False Narrative'. Wardheer News, 27 September 2017. Online: https://wardheernews.com/roots-to-the-somali-massacrechallenging-false-narrative/

Shide, Ahmed, Conflicts along Oromia-Somali States Boundaries: The case study of Babile district. First national conference on federalism, conflict, and peace building, organized by the Ethio-German co-operation (GTZ) of the Federal Governance Development Project in collaboration with the Ministry of Federal Affairs, Addis Ababa, 2004.

Solomon, Salem, 'What's Driving Clashes Between Ethiopia’s Somali, Oromia Regions?' Voice of America, 29 September 2017. Online: www.voanews.com/a/whats-driving-clashesethiopias-somali-oromia-regions/4050017.html

Tenaw, Zigale Tamir, 'Indigenous institutions as an alternative conflict resolution mechanism in eastern Ethiopia: The case of the Ittu Oromo and Issa Somali clans'. African Journal on Conflict Resolution 16, no 2 (2016).

The World Bank Group, GDP per capita (current US\$), 2018. Online: https://data.worldbank. org/indicator/NY.GDP.PCAP.CD

Tibebu, Henok, ‘Crafting Social Media for Better Tomorrow’, 23 November 2017. Online: https://allafrica.com/stories/201711230891.html

Turton, E R, 'Bantu, Galla and Somali Migrations in the Horn of Africa'. The Journal of African History 16, no 4 (1975), 519-537. Online: https://doi.org/10.1017/S0021853700014535

United Nations, Protocol Additional to the Geneva Conventions of 12 August 1949, and relating to the Protection of Victims of Non-International Armed Conflicts (Protocol II), of 8 June 1977.

Worldometer, Department of Economic and Social Affairs, Population Division, World Population Prospects, 2017. Online: www.worldometers.info/world-population/ethiopiapopulation/ 